\title{
ULTRAMORPHOLOGY AND HISTOCHEMISTRY OF FAT BODY CELLS FROM LAST INSTAR LARVAL OF THE Pachycondyla (=Neoponera) villosa (FABRICIUS) (FORMICIDAE: PONERINAE)
}

\author{
ZARA, F. J. ${ }^{1}$ and CAETANO, F. H. ${ }^{2}$ \\ ${ }^{1}$ UNESP, Campus Litoral Paulista, Unidade de São Vicente, Praça Infante Dom Henrique s/n, Parque Bitaru. \\ CEP 13330-900, São Vicente, SP, Brazil \\ ${ }^{2}$ Departamento de Biologia, UNESP, Av. 24a, 1515, C.P. 199, CEP 13506-900, Rio Claro, SP, Brazil \\ Correspondence to: Flávio Henrique Caetano, Departamento de Biologia, UNESP, Av. 24a, 1515, \\ C.P. 199, CEP 13506-900, Rio Claro, SP, Brazil, e-mail: fcaetano@rc.unesp.br \\ Received May 29, 2002 - Accepted May 23, 2003 - Distributed August 31, 2004
}

(With 15 figures)

\begin{abstract}
The fat body cells of Pachycondyla (=Neoponera) villosa are disposed in a single layer between the cuticle and the digestive tract, forming a group of cells enclosed by a thin membrane. Histological studies have revealed three different cellular types: trophocyte (more abundant), urate, (located among the trophocytes), and oenocyte (the scarcest), usually observed laying near the cuticle. Histochemically, the trophocytes showed a positive reaction for basic proteins in the nucleus and cytoplasm, as well as a strong positive reaction in the cytoplasmic granules. The test for carbohydrates showed a strong positive reaction throughout the cytoplasm, while the test for lipids was positive for the cytoplasmic vesicles. The urate cells showed a positive reaction for basic proteins in the nucleus and in the areas of the cytoplasm surrounding the vesicles. These cells did not react to the PAS test or to Sudan Black B. The oenocytes showed a weak positive reaction to PAS and a strong positive reaction to Sudan Black B and Mercuric-bromophenol Blue.
\end{abstract}

Key words: Pachycondyla, fat body, histochemistry, histology, larva.

\section{RESUMO}

\section{Ultramorfologia e histoquímica do corpo gorduroso de larvas de último estágio de Pachycondyla (=Neoponera) villosa (Fabricius) (Formicidae: Ponerinae)}

As células do corpo gorduroso de Pachycondyla (=Neoponera) villosa distribuem-se como uma única camada entre a cutícula e o trato digestivo, formando um conjunto de células agrupadas e recobertas por uma fina membrana. Não foram identificados tipos celulares distintos por meio da ultramorfologia, porém a histologia revelou três tipos celulares distintos: os trofócitos, mais abundantes, as células de urato, distribuídas por entre os trofócitos, e os enócitos, menos abundantes que os demais. Os enócitos são comumente observados próximos da cutícula. Histoquimicamente, os trofócitos apresentaram reação positiva para proteínas básicas no núcleo e no citoplasma e reação fortemente positiva nos grânulos citoplasmáticos. O teste para carboidratos foi fortemente positivo em todo o citoplasma, enquanto para os lipídeos observouse reação positiva nas vesículas citoplasmáticas. Em relação às células de urato, estas apresentaram reação positiva para proteínas básicas no núcleo e citoplasma, por entre as vesículas. Essas células não apresentaram reação para o teste de PAS e Sudan Black B. Quanto aos enócitos, estes apresentaram citoplasma fracamente positivo ao PAS e fortemente positivo ao Sudan Black B e para o azul de bromofenol.

Palavras-chave: Pachycondyla, corpo gorduroso, histoquímica, histologia, larva. 


\section{INTRODUCTION}

The fat body, which has a mesodermic origin (Snodgrass, 1956; Chapman, 1998), is distributed inside the body cavity and exhibits a wide variety of arrangements: ropes, clusters, or lobules (Smith, 1968; Chapman, 1998). Ultramorphological studies of these cells have been performed in adult males and queens of Pachycondyla (=Neoponera) villosa, in which the presence of cytoplasmic junctions was noted (Caetano et al., 1993). The term fat body does not do justice to the versatility of this tissue, since it can sequester and store several compounds from haemolymph, such as proteins, carbohydrates, and lipids. It can also participate in intermediary metabolism, playing a role similar to that of the liver in vertebrates, besides acting as endocrine cells (Locke \& Collins, 1968; Price, 1969; Chapman, 1998). The main cells of the fat body are: the trophocytes or adipocytes, which can be the only cell type in the fat body of several insect orders; the urate cells, present in Collembola, Thysanura, Blattodea, and larval Apocrita (wasps, ants, and bees); the mycetocytes, observed in Hemiptera; and the oenocytes, derived from the epidermis (Chapman, 1998). In general, the fat body of insect larvae has the important function of storing several compounds for pupation (Goitein, 1989). This same author showed that in the last larval instar of Apis mellifera, the reserves consist mainly of lipids. The presence of compounds different from lipids in larvae of Hymenoptera was observed histochemically in Scaptotrigona postica, in which the fat body showed positive reactions for acid and $\alpha$-amino proteins, as well as for carbohydrates (Cruz-Landim \& Mello, 1981).

In this work the ultramorphology, histology, and histochemistry of the fat body cells of larvae of Pachycondyla (=Neoponera) villosa are presented. In addition, we show the distribution of basic proteins, carbohydrates, and lipids by means of histochemical techniques.

\section{MATERIALS AND METHODS}

Larvae of Pachycondyla (=Neoponera) villosa were obtained from artificial nests maintained in the Biology Department at UNESP, Rio Claro, SP, Brazil. The last larval instar of $P$. villos $a$ was detected by measuring the cephalic capsule, according to Zara \& Caetano (2001). For the ultramorphological studies, fat body cells were removed and fixed in
Karnovsky fixative during 24 hours, dehydrated in an ascending alcohol series (70\% to $100 \%)$, subjected to two acetone $100 \%$ baths lasting 15 minutes each, and critical-point dried (Balzers CPD 030). After being dehydrated, the material was placed on aluminum supports, attached with doubleface adhesive, and sputter-coated with gold (Balzers SD 050). The fat body was examined with a Jeol P15 SEM and photographed on Neopan SS 120 film.

For the histological studies, the samples were prepared according to the historesin technique, as follows: the last instar larvae of $P$. villosa were fixed in $4 \%$ paraformaldehyde in $0.1 \mathrm{M}$ phosphate buffer solution ( $\mathrm{pH}$ 7.2). The material was dehydrated in an ascending series of $70 \%, 80 \%, 90 \%$, and $95 \%$ ethanol baths lasting 20 minutes each, and transferred to the resin solution (JB4 - Polaron Instruments/BioRad) for 72 hours at $4^{\circ} \mathrm{C}$. Finally, the material was transferred to molds which were then filled with resin containing a catalyst, and sealed with a metal support for microtomy. After polymerization, the blocks were sliced using a Sorvall JB4/Bio-Rad microtome. The sections were mounted on slides and stained with hematoxylin and eosin.

For the different histochemical analyses, the larvae were treated with specific fixatives for each test, then processed according to the historesin technique described above. The tests performed were: Mercuric-bromophenol Blue for proteins (Gabe, 1976), where the samples were fixed in $4 \%$ Paraformaldehyde; PAS for carbohydrates (Pearse, 1960), using the fixative ethanol/acetic acid (3:1); and Sudan Black B for lipids (Pearse, 1960), with formaldehyde calcium as the fixative. For this last technique, the samples were imbedded in paraffin and sliced using a Leitz microtome. All the sections were mounted on slides, following which they were examined and photographed using the Zeiss photomicroscope.

\section{RESULTS}

The fat body is the main tissue filling the body cavity of Pachycondyla (=Neoponera) villosa larvae. The ultramorphological analysis showed that the fat body is distributed as a single layer between the epidermis and digestive tract, with the cells adhering to each other, forming clusters. Cytoplasmic junctions were not observed among these cells; however, close adherence between them can be noted (Figs. 1 and 2). When the plasma membrane of the fat 
body cells is broken, diverse vesicles are revealed together with amorphous materials (Fig. 2). These vesicles are also noted by the undulated appearance of their membrane (Figs. 1 and 2).
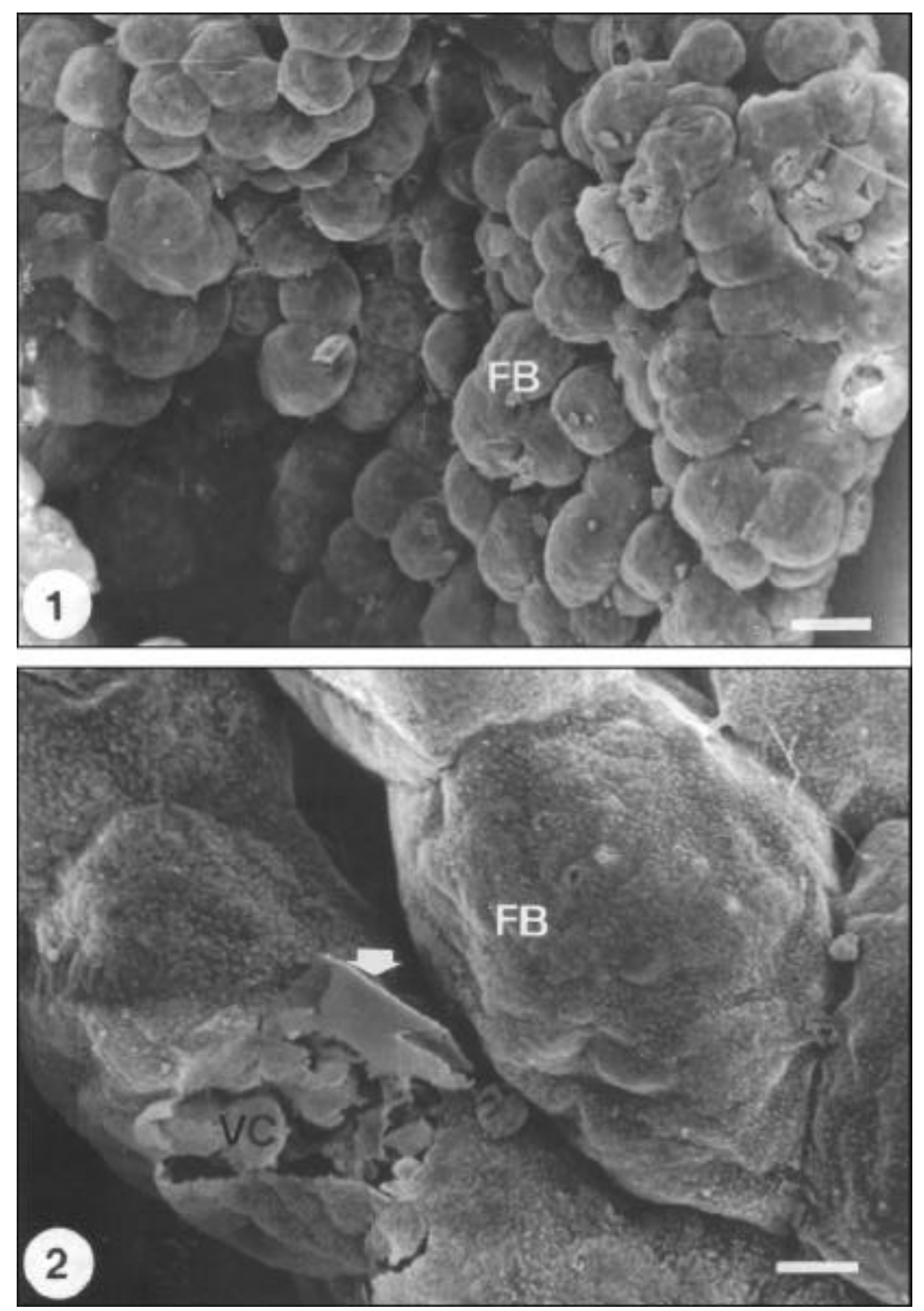

Fig. 1 - General view of the fat body (FB), showing the distribution of the tissue in a single layer with the cells disposed in clusters. Scale bar $=4 \mu \mathrm{m}$. Fig. 2 - Detail of the fat body (FB) showing adherence between the cells; in addition, an opened trophocyte can be observed, displaying cytoplasmic vesicles (VC) together with amorphous materials. The arrow indicates the plasma membrane of fat body cells. Scale bar $=0.9 \mu \mathrm{m}$. 
Histologically, there are no differences among the parietal and perivisceral fat bodies of $P$. villosa, and they show three different cell types: trophocyte, urate, and the oenocyte (Figs. 3 to 6). The trophocyte is the most abundant cell type in the fat body; the cells are rounded and show nuclei with varying sizes and shapes. Several electron-lucid spheres, lipid droplets, and some eosinophil granules (Figs. 3 to 5) can be observed in their cytoplasm. The urate cells, seemingly more abundant next to the ventriculus, are distributed among the trophocytes throughout the body cavity. These cells, recognizable based on their slightly polygonal morphology, show a central nucleus with a large amount of heterochromatin (Figs. 3 and 4). Several small and lucid vesicles can be observed in their cytoplasm (Fig. 4). The last cellular type found in the fat body of $P$. villosa, the oenocytes, present a rounded shape although they can be slightly deformed due to pressure exerted by neighboring cells (Figs. 5, 6, 8, and 11). They show a rounded and large, centrally located nucleus, with a great amount of heterochromatin (Figs. 5 and 6). The cytoplasm is strongly stained by both hematoxylin and eosin $(\mathrm{H}-$ E); it appears flocculated, similar to small vacuoles (Fig. 6). These cells can occur throughout the fat body, but they are more abundant at the periphery of the tissue, near the cuticle. The oenocytes and the urate cells are common in the fat body, nevertheless, they are less numerous than the trophocytes.

Histochemically, the trophocytes present a strong positive reaction to the PAS test for carbohydrates in the cytoplasm (Fig. 7, arrow), whereas the nuclei are negative. By means of this same technique, the urate cells could be observed to present a slightly positive cytoplasm to PAS, especially when compared to the strong reaction shown by the trophocytes; the nuclei gave a negative reaction (Fig. 7). As for the oenocytes, both cytoplasm and nuclei gave a negative reaction to PAS (Fig. 8).

The several cytoplasmic vesicles of the trophocytes displayed a positive reaction to Sudan Black B. These vesicles appeared lucid when stained with H-E, indicating that the stored compounds can be classified as lipid droplets (Fig. 9). The lipid droplets of the trophocytes, stained by Sudan Black, presented different colorations, varying from dark green to black. At high magnifications, it can be noted that the vesicles show black dots inside (Fig. 11, thick arrow). We also verified by Sudan Black that the small granules, which appeared basophiles to H-E, showed a negative reaction for lipids (Fig. 11, thin arrow). The Sudan Black B test also showed that not all the vesicles that were lucid to H-E correspond to lipid droplets. At low magnification, several spaces in the cytoplasm were noted, which seemed to be vacuoles at higher magnifications (Fig. 11). The urate cells showed a negative reaction to Sudan Black B (Fig. 10), whereas the oenocytes demonstrated a strong positive reaction throughout the cytoplasm to Sudan Black B (Fig. 11).

Mercuric-bromophenol Blue revealed that the trophocytes react positively in their cytoplasm, evidencing in this case the presence of basic proteins. The cytoplasmic granules (which reacted negatively to Sudan Black B) showed a particularly strong reaction, indicating that they are, in fact, protein granules with basic characteristics (Figs. 12 to 15). Several lucid vesicles were observed, which could correspond to the lipid droplets or vacuoles, both always negative to the test for basic proteins, which indicates that such droplets do not form complexes with proteins (Figs. 12 and 13). The nuclei of trophocytes showed a strong positive reaction to Mercuric-bromophenol Blue test (Fig. 13). Regarding the urate cells, they showed a positive reaction in their nuclei, especially in the heterochromatin and in the cytoplasm between the small lucid vesicles (Figs. 12 and 13). The cytoplasm of oenocyte reacted positively to Mercuric-bromophenol Blue (Figs. 14 and 15). The nuclei of these cells react strongly positive, particularly in the heterochromatin areas (Fig. 15). The results of all histochemical tests are summarized in Table 1.

\section{DISCUSSION}

The larval fat body of Pachycondyla (=Neoponera) villosa is disposed as a single layer between the cuticle and the digestive tract. Moreover, within this layer, the cells are grouped forming clusters, similar to what is described by Smith (1968) and Chapman (1998) as a general arrangement for insects. When compared to the larval fat body of other Hymenoptera, this one is very similar to that described for the bees Scaptotrigona postica (Cruz-Landim \& Mello, 1981) and Melipona quadrifasciata anthidioides (Cruz-Landim, 1983), and for ants (Athias-Henriot, 1947; Petralia \& Vinson, 1980), although in some species this tissue is reduced (Valentini, 1951). According to Cruz-Landim \& Mello 
(1981), weak adherence is shown among the fat body cells of $S$. postica. This result differs from that based on our observations in P. villosa. Although the fat body cells of $P$. villosa are disposed in a single layer, they are grouped forming clusters, allowing ample adherence between the cells as well as enough free area for exchange with the haemolymph. When compared to the fat body of adults of $P$. villosa, the larval fat body differs in several ways: it is bigger and shows different characteristics, and it lacks cytoplasmic junctions between the cells, such as those observed by Caetano et al. (1993).
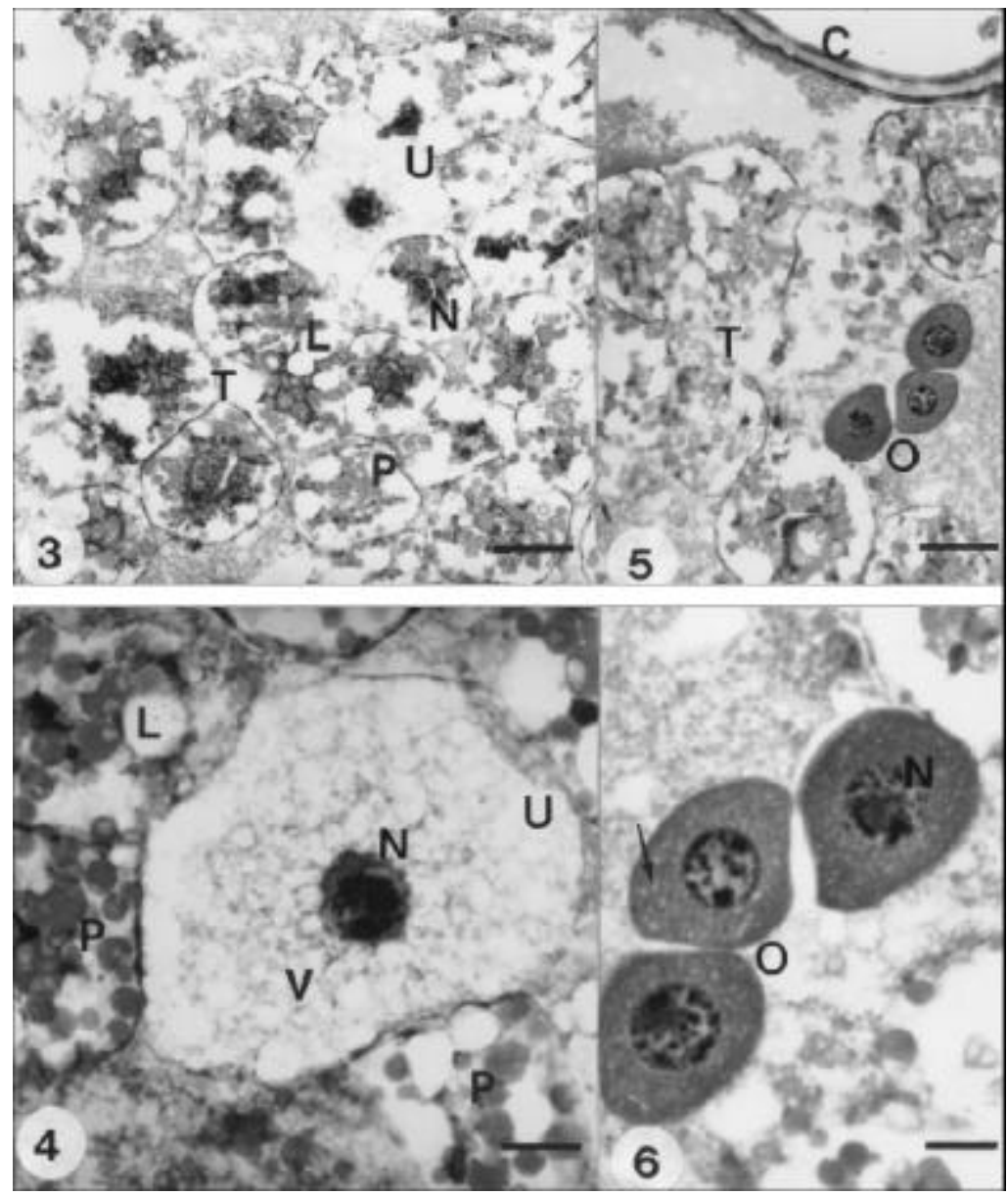

Fig. 3 - General aspect of the fat body of P. villosa showing two cellular types stained by H-E. It is possible to observe that the trophocytes $(\mathrm{T})$ present a series of eosinophil granules that correspond to the protein granules (P) distributed throughout the cytoplasm. In these cells, the presence of several lucid vesicles, the lipid droplets (L), which occupy a large part of the cytoplasm, can be noted. The urate cells $(\mathrm{U})$ appear disposed between the trophocytes. Scale bar $=5 \mu \mathrm{m}$. Fig. 4 - Detail of an urate cell (U) showing its cytoplasm filled with vesicles $(\mathrm{V})$ and with its rounded central nucleus $(\mathrm{N})$ containing a large amount of chromatin. Details of the protein granules $(\mathrm{P})$ are also shown displaying eosinophil characteristics, as well as lipid droplets $(\mathrm{L})$ inside the trophocytes. Scale bar $=2 \mu \mathrm{m}$. Fig. 5 - General view of the third cellular type found in the fat body of $P$. villosa, the oenocytes (O). These cells are disposed mainly underneath the cuticle $(C)$ forming small groups. Scale bar $=5 \mu \mathrm{m}$. $T=$ trophocytes. Fig. $6-$ Detail of the oenocytes $(\mathrm{O})$ showing their large central nuclei $(\mathrm{N})$ containing abundant chromatin. The cytoplasm appears strongly stained by both hematoxylin and eosin and it shows a flocculated aspect reminiscent of small vesicles. Scale bar $=2 \mu \mathrm{m}$. 

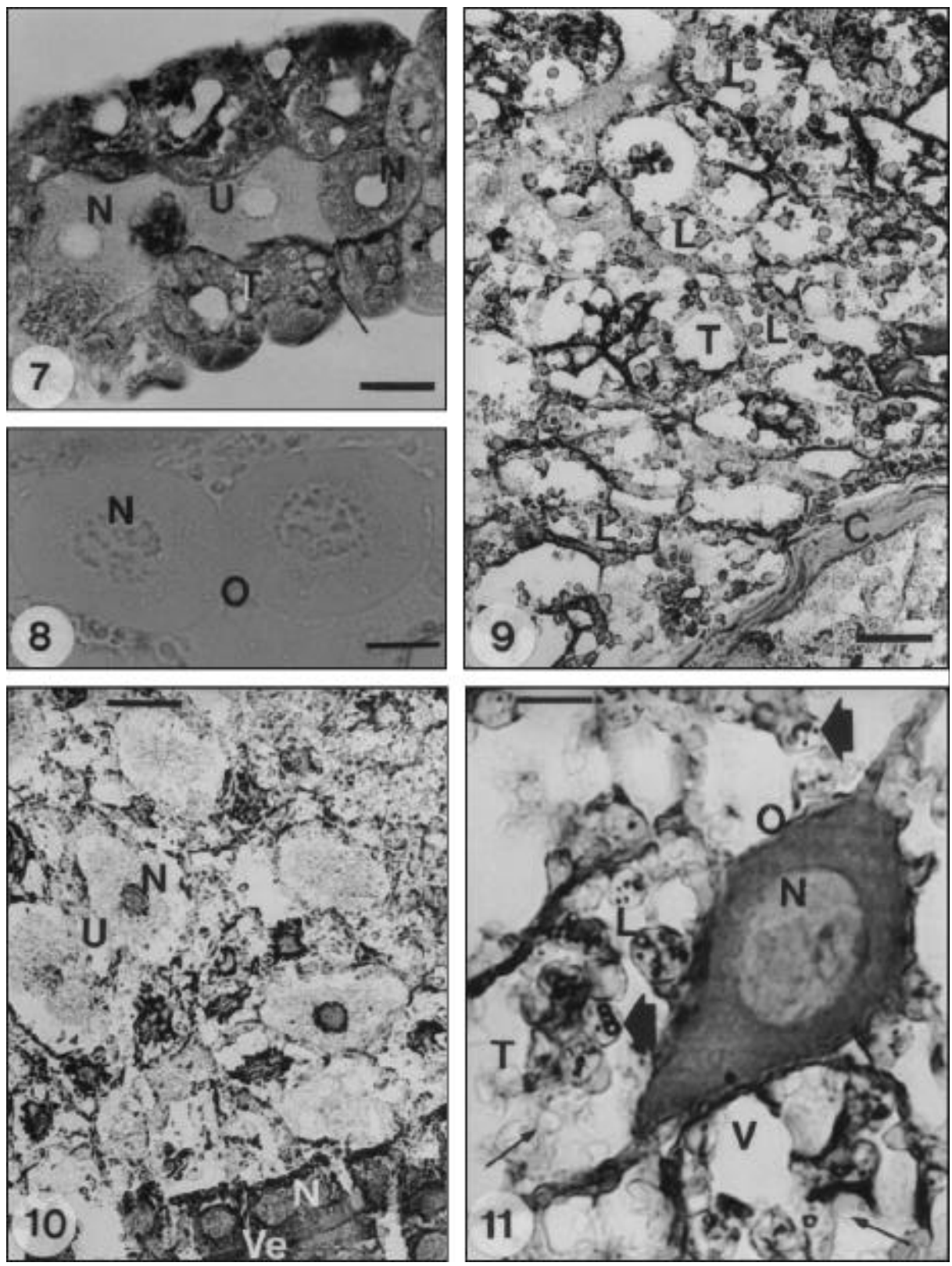

Fig. 7 - Histological section of the fat body cells with PAS positive reaction. Observe that the cytoplasm and periphery of the vesicles (arrow) of the trophocytes $(\mathrm{T})$ show a strong positive reaction. The nuclei $(\mathrm{N})$ of the trophocytes appear negative while the urate cells $(\mathrm{U})$ show a weak positive reaction in their cytoplasm. Scale bar $=5 \mu \mathrm{m}$. Fig. 8 - Detail of the oenocytes $(\mathrm{O})$ subjected to PAS, showing a negative reaction. Scale bar $=2 \mu \mathrm{m} . \mathrm{N}=$ nucleus. Fig. 9 - Histological section of the fat body cells of $P$. villosa submitted to the test of Sudan Black B, in which the cytoplasmic vesicles show a positive reaction for lipids $(\mathrm{L})$. Scale bar $=5$ $\mu \mathrm{m} . \mathrm{T}=$ trophocytes; $\mathrm{C}=$ cuticle. Fig. $\mathbf{1 0}$ - General aspect of the urate cells $(\mathrm{U})$ laying near the ventriculus (Ve) and displaying a negative reaction to the Sudan Black B test. Scale bar $=5 \mu \mathrm{m} . \mathrm{N}=$ nucleus. Fig. 11 - Detail of an oenocyte (O) submitted to the test of Sudan Black B for lipids, showing a strong positive reaction in its cytoplasm. In this image, it can also be observed that the lipid droplets $(\mathrm{L})$ of the trophocytes $(\mathrm{T})$ display differential staining inside them (thick arrows), while the protein granules (thin arrows) react negatively to this test. In addition, lucid vesicles or vacuoles (V) are also noted. Scale bar $=2 \mu \mathrm{m}$. $\mathrm{N}=$ nucleus. 

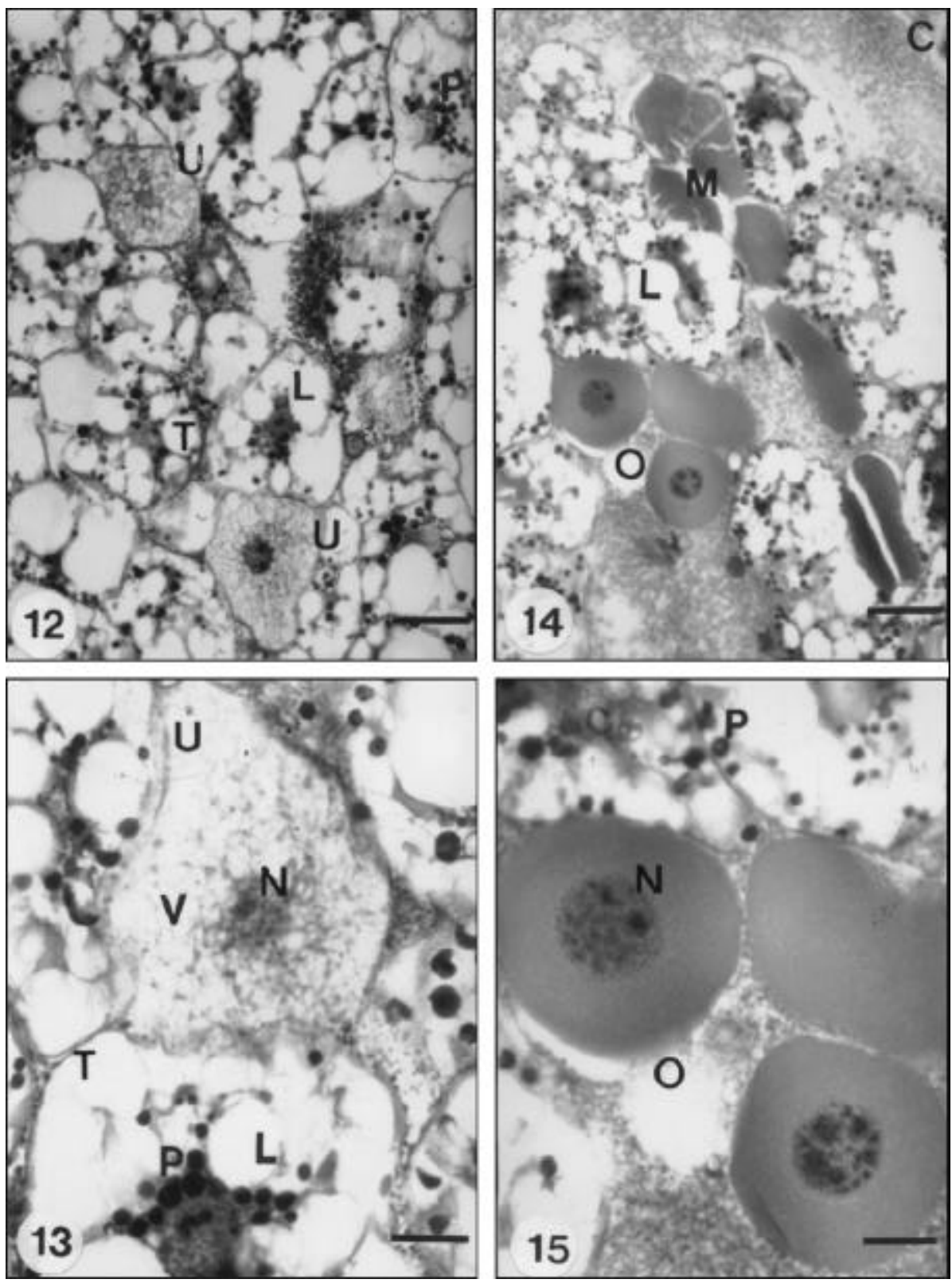

Figs. 12 and 13 - These pictures show fat body cells submitted to the Mercuric-bromophenol Blue test for basic proteins. Note that the trophocytes $(\mathrm{T})$ present a positive reaction in their cytoplasm and nuclei, as well as a strong positive reaction in the protein granules $(\mathrm{P})$. Observe also that the urate cells $(\mathrm{U})$ show a positive reaction in their cytoplasm, as in the areas surrounding the vesicles (V) and in the nucleus (N). Fig. $12-$ Scale bar $=5 \mu \mathrm{m}$, Fig. $13-$ Scale bar $=2 \mu \mathrm{m}$. L $=$ lipid droplets. Figs. 14 and $15-$ Fig. 14 shows the general aspect of oenocytes $(\mathrm{O})$ submitted to the test for basic protein detection, and their distribution near the intersegmentary musculature (M) and the cuticle (C). Scale bar $=5 \mu \mathrm{m}$. In Fig. 15, a detail of these cells shows positive cytoplasm and the nuclei $(\mathrm{N})$, which is strongly positive, mainly at the chromatin. Scale bar $=2 \mu \mathrm{m}$. $\mathrm{O}=$ oenocytes; $\mathrm{P}=$ protein granules. 
Histologically, the trophocytes of the last larval instar of $P$. villosa generally present rounded nuclei, although they may assume different shapes due to the pressure caused by materials accumulated in the cytoplasm. These nuclei possess a large amount of heterochromatin, and no indications of cellular division were observed in these cells at any time. This description of trophocytes agrees with that of Cruz-Landim (1983). Several lucid vesicles and eosinophil granules can be found in the cytoplasm.

Among these vesicles lucid to H-E, some gave a positive reaction to the Sudan Black B test for lipids, indicating that some of them are lipid droplets. The presence of such components was also observed in the fourth and fifth larval instars of S. postica (CruzLandim \& Mello, 1981) and M. q. anthidioides (CruzLandim, 1983). However, during the last two larval instars, a distribution reorganization of these components seemed to occur in these bees, by which the protein granules tended to concentrate around the nucleus, while the lipid droplets were more frequently found at the cell periphery. This kind of cytoplasmic distribution of lipid droplets and eosinophil granules was not observed in the last larval stage of $P$. villosa.

With regard to ants, in Solenopsis invicta the trophocytes appear to be constituted mainly by lipid droplets; the presence of protein granules has not been registered (Petralia \& Vinson, 1980). On the other hand, in addition to lipid droplets the presence of several eosinophil granules inside the trophocytes was noted in Eciton burchelli (Lappano, 1958), in Neivamyrmex nigrescens (Wang \& Happ, 1974), and in several species of ants studied by Valentini (1951). The granules found in P. villosa show a strong positive reaction when subjected to the Mercuric-bromophenol Blue test for proteins, particularly those with basic properties (Gabe, 1976), indicating that such structures are in fact protein granules. This shows that the larval fat body of $P$. villosa also accumulates proteins in the shape of granules, in a manner similar to that described for S. postica (Cruz-Landim \& Mello, 1981) and $M$. q. anthidioides (Cruz-Landim, 1983). In addition, since eosinophil granules have also been observed in several species of ants (Valentini, 1951; Lappano, 1958; Wang \& Happ, 1974), based on the results obtained in P. villosa, it can be assumed that such granules would also be constituted by proteins.

The suggestion that these eosinophil granules could be forms of protein storage has been proposed in a single work for the ant $N$. nigrescens (Wang \& Happ, 1974) and is supported by our results. The presence of protein granules has been described for several insect orders, besides Hymenoptera, such as Coleoptera, Diptera, Lepidoptera, and Orthoptera (Dean et al., 1985). The function of these granules is related to the storage of proteins for metamorphosis, and the presence of these granules can be visualized during the last larval instar (Price, 1969; Locke, 1984; Dean et al., 1985). Additionally, in M. q. athidioides, protein granule development begins during the second larval instar. Granules increase in number until the fifth instar when they seem to be activated (Cruz-Landim, 1983). An analogous event also occurs in S. postica when, however, protein granule emergence begins at the third larval instar. Although the present work only deals with the fourth (last) larval instar, we must mention that the protein granules of $P$. villosa can be observed only during this instar. This result was verified by analyzing trophocyte images close to the salivary gland during the larval development of $P$. villosa (Zara, 1995). That the presence of these granules can only be noted during the last larval instar agrees with observations made by Locke (1984), Dean et al. (1985), and Keeley (1985).

Besides proteins, the trophocytes also store lipids and glycogen which they themselves produce or sequester from hemolymph (Bishop, 1922; Price, 1969; Dean et al., 1985; Keely, 1985). Such compounds are present in P. villosa and they were identified through the histochemical tests of Sudan Black B and PAS, respectively. Most of the vesicles lucid to H-E showed a positive reaction to Sudan Black B; these can be found distributed throughout the cytoplasm, although unlike S. postica, M. q. anthidioides, and N. nigrescens (Cruz-Landim \& Mello, 1981; Cruz-Landim, 1983; Wang \& Happ, 1974 , respectively) they were not observed concentrated at the periphery.

These lipid droplets reacted with differential intensities to Sudan Black B: at low magnifications, they showed a green stain; however, at higher magnification black spots can be observed inside the droplet. These black spots are probably a by product of the technique.

According to Keeley (1985), lipids are stored in the insect fat body as triglycerides, and the main fatty acids observed are palmitic, palmitoleic, stearic, oleic, linoleic, and linolenic acids. The presence 
of fatty acids in $P$. villosa was confirmed by chemical analyses. Using chromatography and mass spectrometry, the presence of unsaturated fatty acids such as oleic and linoleic acids and saturated palmitic and stearic acids was observed (Zara et al., 2002).

The reaction obtained for Sudan Black B showed that not all vesicles that were lucid when stained with H-E are lipid droplets. Therefore, the trophocytes may present vacuoles mainly during the last larval instar, similar to those observed in Leptinotarsa, Phormia, Manduca, and Hyalophora (Dean et al., 1985). Such vacuoles might be storing tyrosine or other phenolic precursors needed for cuticular tanning during metamorphosis. In connection with this hypothesis, mention should be made of the fact that the protein granules observed in $P$. villosa showed a strong positive reaction to Mercuric-bromophenol Blue, indicating the presence of basic proteins. According to Chapman (1998), basic aminoacids are needed during the tanning process, which are also the main constituents of cuticular proteins. In order to elucidate this question, analysis through transmission electron microscopy is necessary to determine the presence of vacuoles, mainly during the last larval instar.

The PAS histochemical test evidenced a strong positive reaction throughout trophocyte cytoplasm in $P$. villosa. Using the same technique, strong positive reactions were also detected in the last two larval instars of $S$. postica (Cruz-Landim \& Mello, 1981) and M. q. anthidioides (Cruz-Landim, 1983). Although the PAS technique is used for the identification of aminoacids that contain free $\mathrm{OH}$ groups adjacent to carbon chains (1:2 glycol), it does not guarantee specificity, and several sugars, such as amides, cellulose, and glycogen (Pearse, 1960) can give a positive reaction. Since glycogen is the main carbohydrate stored in the fat body of insects (Kilbe, 1963; Keeley, 1985), the strong positive reactions obtained for PAS in the trophocytes of $P$. villosa might indicate the presence of this carbohydrate. Carbohydrates, one of the main metabolites synthesized and liberated into the hemolymph from the fat body, serve as an energy source for all tissues (Keeley, 1985). In the case of $P$. villosa, as well as in that of other insects, carbohydrates are probably stored as glycogen.

Another cellular type found in the fat body of $P$. villosa is the urate. Urocytes are irregularly shaped, generally larger than trophocytes, and their cytoplasm is filled with vesicles. The nucleus is rounded, centrally located, and has a large amount of chromatin. No indications of cellular divisions were observed in the urocytes. This description parallels those made for the bees Apis mellifera (Nelson, 1924) and S. postica (Cruz-Landim \& Mello, 1981), as well as those made for several species of ants by Athias-Henriot (1947) and $S$. invicta (Petralia \& Vinson, 1980). Nevertheless, it differs from the description made by Pérez (1901, 1902, cited in Athias-Henriot, 1947) for Lasius flavus and Formica rufa, in which the uracytes are smaller than the trophocytes. In P. villosa, although these cells are disposed throughout the larval body, they seem to be more concentrated near the ventriculus, as happens in S. invicta according to observations made by Petralia \& Vinson, 1980. These cells occur in other insect orders besides Hymenoptera, e.g., Collembola, Thysanura, Lepidoptera, and Blattodea (Chapman, 1998). Their function is related to the storage of uric acid, the main final product resulting from the metabolism of nitrogen compounds (Chapman, 1998; Keeley, 1985). According to Cruz-Landim \& Mello (1981), the urate cells are only observed beginning from the fourth larval instar, and this event is related to an excretion product overload inside the Malpighian tubules. Such an event does not occur in P. villosa, since an analysis of the fat body cells adjacent to the salivary gland during larval development reveals the presence of urate cells from the first instar (Zara, 1995). Similarly, Nelson (1924) recorded the presence of numerous urate cells in two-day-old Apis mellifera larvae.

Histochemically, the urate cells show a strong positive reaction for the protein test, as revealed by the Mercuric-bromophenol Blue technique. Both nuclei and cytoplasm reacted positively, which might be related to the presence of nuclear proteins, e.g., histones, and proteins found in the cytoplasmic areas surrounding the vesicles. In addition, the cytoplasm also shows a positive reaction to the PAS test for carbohydrates. However, this reaction is much weaker when compared to the strong reaction shown by the trophocytes. With regard to the Sudan Black B test for lipids, the urocytes showed a negative reaction. Although Cruz-Landim \& Mello (1981) and Cruz-Landim (1983) have studied the histochemical aspects of the bee larval fat body, 
their research did not include the histochemistry of urate cells.

The last cellular type identified in the larval fat body of $P$. villosa is the oenocyte which presents various shapes, from rounded to ellipsoid form. The oenocytes have a single, large, and rounded central nucleus with abundant chromatin. Their cytoplasm reacts strongly positive to both hematoxylin and eosin and their appearance is flocculated, reminiscent of small vacuoles, details amply registered in the literature for Hymenoptera (Nelson, 1924; Athias-Henriot, 1947; Cruz-Landim \& Mello, 1981). Oenocytes are distributed among the trophocytes, right underneath the epidermis, being more commonly found forming small groups of 3 to 5 cells, although also found isolated, especially near the digestive tract. These cells can be observed in both the thoracic and dorsal abdominal areas, being more abundant in the latter close to the intersegmentary musculature. A similar arrangement is found in larvae of other ants (Pérez, 1902, cited in Athias-Henriot, 1947; Athias-Henriot, 1947; Petralia \& Vinson, 1980) and bees (Snodgrass, 1956; Cruz-Landim \& Mello, 1981), though in honeybees they are only observed in the abdominal portion (Nelson, 1924). Thus, the only difference noted between the peripheral fat body cells in relation to those lying near the digestive tract consists in the presence of oenocytes in greater abundance underneath the cuticular epidermis. Such an arrangement seems normal in larval tissues, since oenocytes originate ectodermally origin (Cruz-Landim \& Mello, 1981; Dean et al., 1985; Chapman, 1998). Histochemically, the oenocytes reacted almost completely negatively to the PAS test for carbohydrates. This result agrees with the observations made, using the same technique, by Cruz-Landim \& Mello (1981) of the oenocytes of $S$. postica. These observations suggest that oenocytes do not seem to store or utilize large carbohydrate amounts in producing their compounds. On the other hand, oenocyte cytoplasm shows strong positive reaction to both lipids and proteins. The reaction to lipids, detected by the Sudan Black B technique, can easily be understood, since oenocytes synthesize hydrocarbons and other cuticular lipids (Cruz-Landim \& Mello, 1981; Chapman, 1998). Moreover, the ultrastructural description of these cells reveals an ample system of tubules in a smooth endoplasmic reticule (Dean et al., 1985; Chapman, 1998), which might also be present in these cells in $P$. villosa. The positive reaction for proteins displayed by the oenocytes of $P$. villosa indicates that these cells do not produce lipidic compounds exclusively, but that they might also be producing lipoproteic compounds, such as the lipoproteins that carry the juvenile hormone, the so-called JH-carrier lipoprotein. According to Keeley (1985), these lipoproteins are produced by the fat body of Manduca sexta and Locusta migratoria, though the cellular type producing them is not mentioned. They may have either low or high molecular weight depending on the species, and their function is to increase solubility of the juvenile hormone in the hemolymph and prevent its degradation by non-specific esterases.

In conclusion, the fat body of $P$. villosa shows three distinct cellular types, of which the trophocytes and the urocytes cells specialize in the storage of nutrients and excretion products, respectively, while the oenocytes seem to be in charge of producing lipid compounds for the cuticle. During the last larval instar, the trophocytes are clearly storing large carbohydrate (glycogen), lipids, and protein amounts which in addition to being mobilized during metamorphosis, act in larval metabolism maintenance until pupation. The urate cells yielded poor histochemical information, which could indicate an excretion product storage function, as has been widely mentioned in the literature. The oenocytes, in addition to producing cuticular lipids, could also be involved in the synthesis of JH-carrier lipoproteins, and in connecting this tissue to the endocrine system. Thus, histologically and histochemically, the larval fat body of this ant displays all the characteristics necessary for being the center of larval intermediate metabolism.

Acknowledgements - This work was supported by the Brazilian research agency FAPESP (Fundação de Amparo à Pesquisa do Estado de São Paulo) proc. 98/00576-8.

\section{REFERENCES}

ATHIAS-HENRIOT, C., 1947, Recherches sur les larves de quelques fourmis d'Algérie. Bull. Biol. Fr. Belg., 81: $247-$ 272 .

BISHOP, G. P., 1922, Cell metabolism in fat body. J. Morphol., 36: $567-601$.

CAETANO, F. H., CAMARGO-MATHIAS, M. I. \& TOMOTAKE, M. E. M., 1993, Ultra estrutura do corpo gorduroso viceral de formigas Neoponera villosa (Hymenoptera: Ponerinae): Pontes citoplasmáticas. In: Anais XIV Congresso da SBME. Caxambu, pp. 253-254. 
CHAPMAN, R. F., 1998, The insects: structure and function. Cambridge University Press, Cambridge, 770p.

CRUZ-LANDIM, C., 1983, O corpo gorduroso da larva de Melipona quadrifasciata anthidioides Lep. (Apidae, Meliponinae). Naturalia, 8: 7-23.

CRUZ-LANDIM, C. \& MELLO, R. A., 1981, Desenvolvimento e envelhecimento de larvas e adultos de Scaptotrigona postica Latraille (Hymenoptera: Apidae): aspectos histológicos e histoquímicos. ACIESP, São Paulo, 118p.

DEAN, R. L., LOCKE, M. \& COLLINS, J. V., 1985, Structure of the fat body, pp. 155-210. In: G. A. Kerkut and L. I. Gilbert (eds.), Comprehensa insect physiology, biochemistry and pharmacology. Pergamont Press, London, vol. 9.

GABE, M., 1976, Histological techniques. Springer Verlag, New York, 1106p.

GOITEN, M. R. C., 1989, Estudos morfológicos e morfométricos do corpo gorduroso e enócitos de Apis mellifera $L$. (Hymenoptera, Apidae) durante o desenvolvimento larval. Dissertação de Mestrado, UNESP, Rio Claro, SP, 77p.

KEELEY, L. L., 1985, Physiology and biochemistry of fat body. Structure of the fat body, pp. 211-248. In: G. A. Kerkut \& L. I. Gilbert (eds.), Comprehensive insect physiology biochemistry and pharmacology. Pergamont Press, London, vol. 9.

KILBE, B. A., 1963, The biochemistry of the insect fat body. Arch. Insect Physiol., 1: 111-174.

LAPPANO, E. R., 1958, A morphological study of larval development in polymorphic all-worker broods of the army ants Eciton burchelli. Insectes Soc., 5: 31-66.

LOCKE, M., 1984, The structure and development of vacuolar system in the fat body of insects, pp. 151-197. In: R. C. King \& H. Akai (eds.), Insect ultrastructure. Plenum Press, New York, vol. 2.

LOCKE, M. \& COLLINS, J. V., 1968, Protein uptake into multivesicular bodies and storage granules in the fat body of an insect. J. Cell. Biol., 36: 453-483.
NELSON, J. A., 1924, Morphology of the honeybee larva. $J$. Agric. Res., 28: 1167-1229.

PEARSE, A. G. E., 1960, Histochemistry: theoretical and applied. J. \& A. Churchill, London, 998p.

PETRALIA, R. S. \& VINSON, S. B., 1980, Internal anatomy of fourth instar larva of imported fire ant, Solenopsis invicta Buren (Hymenoptera: Formicidae). Int. J. Insect Morphl \& Embriol., 8: 89-106.

PRICE, G. M., 1969, Protein synthesis and nucleic acid metabolism in the fat body of the blowfly, Calliphora erythrocephala. J. Insect Physiol., 15: 931-944.

SMITH, D. S., 1968, Insect cell: their structure and function. Oliver \& Boyd, Edinburgh, 372p.

SNODGRASS, R. E., 1956, Anatomy of the honey bee. Comstock, New York, 334p.

VALENTINI, S., 1951, Sur L'adaptacion des larves de Formicoidea. Ann. Des Sc. Nat. Zool., 11: 249-76.

WANG, Y. J. \& HAPP, G. M., 1974, Larval development during the nomadic phase of neartic army ant, Neivamyrmex nigriscens (Cresson)(Hymenoptera: Formicidae). Int. J. Insect Morphl \& Embryol., 3: 73-86.

ZARA, F. J., 1995, Estudo anatomo-histológico da glândula salivary larval de formigas Neoponera villosa (Hymenoptera: Formicidae) durante sua fase larval. Monografia, UNESP, Rio Claro, SP, 62p.

ZARA, F. J. \& CAETANO, F. H., 2001, Number of larval instars of the ant Pachycondyla (=Neoponera) villosa (Formicidae: Ponerinae) determined by the rule of Dyar. Sociobiology, 38: 679-686.

ZARA, F. J., CABRERA, A. C., JAFFÉ, K. \& CAETANO, F. H., 2002, Chemical analysis of different larval instars and tissues of Pachycondyla (=Neoponera) villosa (Hymenoptera: Formicidae, Ponerinae). Sociobiology, 39: 89-101. 